\title{
Growth and yield behavior of barley varieties under agro-climatic conditions of Turbat, Balochistan
}

Shahab-u-Din ${ }^{1 *}$, Nazeer Ahmed ${ }^{1}$, Muhammad Nawaz Kandhro ${ }^{2}$, Mukhtar Umer ${ }^{3}$, Muhammad Yaqoob ${ }^{4}$, Shafique Ahmed ${ }^{1}$ and Ayaz Ahmed Lashari ${ }^{5}$

1. Agricultural Research Institute (BAR\&DC), PARC, Turbat-Pakistan

2. Department of Agronomy, SAU, Tandojam-Pakistan

3. Date Research Center Turbat-Pakistan

4. Horticulture Research Institute (BAR\&DC), PARC, Khuzdar-Pakistan

5. Agriculture Extension Department, Government of Balochistan-Pakistan

*Corresponding author's email: shahabkashani64@gmail.com

Citation

Shahab-u-Din, Nazeer Ahmed, Muhammad Nawaz Kandhro, Mukhtar Umer, Muhammad Yaqoob, Shafique Ahmed and Ayaz Ahmed Lashari. Growth and yield behavior of barley varieties under agro-climatic conditions of Turbat, Balochistan. Pure and Applied Biology. Vol. 6, Issue 4, pp1522-1526.

http://dx.doi.org/10.19045/bspab.2017.600164

Received: 05/10/2017 Revised: 06/12/2017

Accepted: 10/12/2017

Online First: 11/12/2017

\section{Abstract}

The development of high yielding and drought tolerant cultivars of cereal crops is one of the main goals of agriculture researchers due to ever increasing demand of food for rapidly increasing human population and decreasing water resources. The field study was conducted at Agricultural Research Institute, PARC, Turbat during Rabi 2014-15 to determine the growth and yield performance of various barley varieties. This experiment was designed as randomized complete block design with three replications and net plot size kept was $5 \mathrm{~m} \times 3 \mathrm{~m}\left(15 \mathrm{~m}^{2}\right)$. The treatments comprised of six barley cultivars i.e. Sorab-96, Rakhshan-10, Sanober-96, Awaran-2002, Local Turbat and Local Dasht. The statistiacal analysis of data showed that growth and yield of barley crop was significantly $(\mathrm{P} \leq 0.05)$ affected by genotypic variation. The data revealed that significantly $(\mathrm{P} \leq 0.05)$ maximum growth and yield traits particularly grain yield $\left(1791 \mathrm{kgha}^{-1}\right)$ was recorded in variety Rakhshan-10, followed by Awaran-2002 with grain yield of $1657 \mathrm{kgha}^{-1}$. The barley grain yield declined to 1625,1619 and $1521 \mathrm{~kg} \mathrm{ha}^{-1}$ in varieties Sanober-96, Local Dasht and Local Turbat ranked, respectively. However, lowest barley grain yield of $1459 \mathrm{~kg} \mathrm{ha}^{-1}$ was observed in variety Sorab-96. Hence, it is concluded from the results that barley variety Rakhshan10 may preferably be sown under agro-climatic conditions of Turbat as it showed best yield performance over rest of the barley varieties.

Keywords: Barley; Growth; Yield; Varieties; Agro-climate; Turbat; Balochistan

\section{Introduction}

Barley (Hordeum vulgare L.) is known as significant cereal crop that ranks $4^{\text {th }}$ by production and $5^{\text {th }}$ by cultivation among cereals throughout the world [1]. It is an important crop in the world mainly used for animal feed and malt and considered as salinity tolerant crop. It also used in bread 
making and other human food and beverages soup stew etc. Barley bread is of in numerable cultures. Gluten is the main ingredient of barley, distilled and base malt beer. Barley is a very drought tolerant crop. It can perform better in adverse agro climatic conditions, as well as rain fed areas [2].

Different biotic and abiotic factors adversely affect the crop production. It is challenging to ensure food security by minimizing these losses under changing climatic conditions and water shortage [3]. Many varieties that produce high yield have been evolved and recommended for general cultivation in the past. These varieties are losing their yield potential because of changes in various edaphic and environmental conditions. So, constant choice of high producing genotypes with mid-range of adaptability to edaphic and ecological conditions is most vital factors to increase yield per unit area [4]. The yield of a crop is affected by genotypic, physical and biotic factors. The evaluation of cultivars for yield performance is influenced by soil type, climate and presence of diseases and other harmful agents. The cultivar evaluation trials are carried out to provide a basis for the recommended lists of varieties being released for general cultivation in many countries. The objective of such studies is to help growers choose cultivars which are most likely to give them the maximum returns under their agroclimatic conditions [5].

Drought, being the most important environmental stress, severely impairs plant growth and development, limits plant production and the performance of crop plants, more than any other environmental factor [6].The drought tolerant cultivars have got universal attention. The suitable cultivar adapted with environmental condition and tolerant to water stress is one of the limited factors in barley production. Improved farm practices are important to achieve higher yields [7]. Previous research suggested that barley cultivars: Sanober-96 and Awaran-
2002 at the seed rate of $120 \mathrm{~kg} \mathrm{ha}^{-1}$ gave maximum grain yield under moisture stress condition of Khyber Pakhtunkhwa, Pakistan [8]. Many researchers found that crops differ in their growth and yield response to unfavorable condition [9]. It is now well established that grain yield in barley should be considered as being made up of various components and that they in turn are influenced by cultivar, husbandry practices and environment affecting through physiological processes [5]. Therefore, the objective of this research was to examine the growth and yield performance of some barley varieties under agro-climatic conditions of Turbat, Balochistan, Pakistan.

\section{Materials and methods}

A field trial was conducted at Agricultural Research Institute, PARC, Turbat during Rabi, 2014-15 under three replicated randomized complete block design having net plot size $5 \mathrm{~m}$ $\times 3 \mathrm{~m}\left(15 \mathrm{~m}^{2}\right)$. The barley cultivars viz., Sorab96, Rakhshan-10, Sanober-96, Awaran-2002, Local Turbat and Local Dasht were sown for this study. The soil type was clay loam. Before sowing seed, the land was irrigated. After soaking dose, when $\mathrm{t}$ he land came in condition, it was ploughed two times by cultivator followed by planking (wood board). The seed was sown on $20^{\text {th }}$ November, 2014 @ $150 \mathrm{~kg} \mathrm{ha}^{-1}$ through drilling. Nitrogen and Phosphorus were applied at recommended rate of 90 and $60 \mathrm{~kg} \mathrm{ha}^{-1}$ in the form of Urea and SSP. Full dose of $\mathrm{P}$ and $1 / 3^{\text {rd }}$ of $\mathrm{N}$ was applied at the time of sowing whereas remaining $\mathrm{N}$ was applied in two equal splits at $1^{\text {st }}$ and $2^{\text {nd }}$ irrigation. The weeds were controlled through hand pulling twice at $1^{\text {st }}$ and $2^{\text {nd }}$ irrigation.

\section{Observations recorded}

The data was collected on plant height $(\mathrm{cm})$, grains spike ${ }^{-1}$, grain yiel $\left(\mathrm{kg} \mathrm{ha}{ }^{-1}\right)$ and biomass yield $\left(\mathrm{kg} \mathrm{ha}^{-1}\right)$. 


\section{Statistical analysis}

The data collected was subjected to analysis of variance technique using Statistics ver. 8.1 (Statistics, 2006). The least significant difference test was applied to compare superiority of varieties at probability level of 0.05 .

\section{Meteorological data}

The meteorological data of Turbat, Balochistan regarding minimum temperature, maximum temperature, relative humidity and rainfall during Rabi, 2014-15 is presented in (Table 1).

Table 1. Average monthly meteorological data of Turbat, Balochistan during Rabi, 201415

\begin{tabular}{|c|c|c|c|c|}
\hline \multicolumn{5}{|c|}{2014} \\
\hline \multirow{2}{*}{ Month } & \multicolumn{2}{|c|}{ Temperature $\left({ }^{0} \mathrm{C}\right)$} & \multirow{2}{*}{$\begin{array}{c}\text { Relative } \\
\text { Humidity (\%) }\end{array}$} & \multirow{2}{*}{$\begin{array}{c}\text { Rainfall } \\
(\mathrm{mm})\end{array}$} \\
\hline & Minimum & Maximum & & \\
\hline November & 18.9 & 34.4 & 70.5 & 0.0 \\
\hline December & 15.1 & 31.3 & 74.3 & 0.0 \\
\hline \multicolumn{5}{|c|}{2015} \\
\hline January & 18.9 & 29.8 & 73.8 & 0.0 \\
\hline February & 20.8 & 31.8 & 85.3 & 0.0 \\
\hline March & 23.6 & 35.5 & 72.5 & 0.0 \\
\hline April & 26.9 & 43.3 & 65.8 & 0.0 \\
\hline
\end{tabular}

Source: Meteorological Observatory Station, Turbat, Balochistan

\section{Results and discussion}

\section{Plant height}

The results (Table 2) revealed that plant height was significantly affected among different varieties of barley. In Local Dasht variety the maximum plant height of $74.4 \mathrm{~cm}$ was observed followed by Rakhshan-10 with74.2 cm. Varieties Awaran-2002 and Local Turbat ranked $2^{\text {nd }}$ showing plant height of $63.8 \mathrm{~cm}$ with non-significant differences to each other. The plant height of Sorab-96 variety diminished to $55.5 \mathrm{~cm}$. However, minimum plant height $(47.1 \mathrm{~cm})$ was recorded in variety Sanober-96. The overall mean plant height was observed as $63.1 \mathrm{~cm}$. The difference in plant height among various varieties of barley was perhaps due to their genetic constitution. These results are in line with those of $[1,12]$ who reported that plant height significantly varied among different genotypes of barley. Similar results were also reported by [5] who found considerable variation among barley varieties for plant height.

\section{Grains spike ${ }^{-1}$}

Number of grains spike ${ }^{-1}$ is an important yield contributing factor of barley which is significantly influenced by the prevailing growing conditions and genetic potential of a cultivar. The highest number of grains spike ${ }^{-}$ 1 (20.1) was produced by variety Rakhshan10 which differed significantly from other cultivars (Table 2). Similarly, Local Turbat, Sorab-96 and Local Dasht were also at par in the number of grains (13.3, 12.9 and 12.5) with each other. The lowest and statistically similar number of grains spike ${ }^{-1}$ (10.1 and 8.7) was produced by Awaran-2002 and Sanober-96. New varieties of barley have been found to produce additional grains spike $^{1}$ than old tall varieties probably due to more favorable distribution of assimilate to the spike. Commonly, new semi-dwarf cultivars partition more dry matter to the spikes and less to the stem, and this is reflected in more flowerets and grains spike ${ }^{-1}$ than in common standard cultivars. The 
enhancement of growth and produce of barley cultivars was also described by [10]. Variation in the number of grains spike ${ }^{-1}$ of different varieties might be due to the inherited characters of the genotypes and thus certain variety had more grains spike ${ }^{-1}$ from other due to the best suits with the prevailing environmental condition [11].

Table 2. Growth and yield of barley varieties under agro-climatic conditions of Turbat, Balochistan

\begin{tabular}{|c|c|c|c|c|}
\hline Varieties & $\begin{array}{c}\text { Plant height } \\
(\mathbf{c m})\end{array}$ & $\begin{array}{c}\text { Grains } \\
\mathbf{s p i k e}^{-1}\end{array}$ & $\begin{array}{c}\text { Grain yield } \\
\left(\mathbf{k g h a}^{-1}\right)\end{array}$ & $\begin{array}{c}\text { Biomass } \\
\mathbf{( k g h a}^{-1} \mathbf{~}\end{array}$ \\
\hline Sorab-96 & $55.5 \mathrm{c}$ & $12.9 \mathrm{~b}$ & $1459 \mathrm{e}$ & $3878 \mathrm{~b}$ \\
\hline Rakhshan-10 & $74.2 \mathrm{a}$ & $20.1 \mathrm{a}$ & $1791 \mathrm{a}$ & $4885 \mathrm{a}$ \\
\hline Sanober-96 & $47.1 \mathrm{~d}$ & $8.7 \mathrm{~d}$ & $1625 \mathrm{c}$ & $3164 \mathrm{e}$ \\
\hline Awaran-2002 & $63.8 \mathrm{~b}$ & $10.1 \mathrm{c}$ & $1657 \mathrm{~b}$ & $3829 \mathrm{c}$ \\
\hline Local Turbat & $63.8 \mathrm{~b}$ & $13.3 \mathrm{~b}$ & $1521 \mathrm{~d}$ & $2857 \mathrm{f}$ \\
\hline Local Dasht & $74.4 \mathrm{a}$ & $12.5 \mathrm{~b}$ & $1619 \mathrm{c}$ & $3581 \mathrm{~d}$ \\
\hline S.E \pm & 0.5172 & 0.3755 & 4.7046 & 18.301 \\
\hline LSD 0.05 & 1.1524 & 0.8368 & 10.483 & 40.778 \\
\hline P-value & 0.0000 & 0.0000 & 0.0000 & 0.0000 \\
\hline
\end{tabular}

Values followed by different letters in each column are significantly different at $\mathrm{P} \leq 0.05$

\section{Grain yield (kg ha-1)}

Grain yield is a function of interplay of various components of yield such as number of fertile tillers unit ${ }^{-1}$ area, number of grains spike $^{-1}$ and 1000-grain weight. It is evident from the (Table 2) that there were significant differences among various wheat cultivars regarding grain yield $\left(\mathrm{kg} \mathrm{ha}^{-1}\right)$. The barley variety Rakhshan-10 produced maximum grain yield of $1791 \mathrm{~kg} \mathrm{ha}^{-1}$ followed by Awaran-2002 with $1657 \mathrm{~kg}$ ha $^{-1}$. Varieties Sanober-96 and Local Dasht ranked $3^{\text {rd }}$ and statistically at par with each other resulting in grain yield of 1625 and $1619 \mathrm{~kg} \mathrm{ha}^{-1}$, respectively. Barley grain yield declined to $1521 \mathrm{~kg} \mathrm{ha}^{-1}$ in variety Local Turbat. However, minimum grain yield $\left(1459 \mathrm{~kg} \mathrm{ha}^{-}\right.$ $\left.{ }^{1}\right)$ was obtained in variety Sorab-96. The higher grain yield in Rakhshan-10 over other varieties may be ascribed to higher quantity of grains spike ${ }^{-1}$. Genetic diversity in crop plants shows their prospect for improved efficiency [10]. The yield components tend to compensate as ear population and grain set are inversely related. The results are in accordance with [8] who reported disparity among different cultivars for grain yield.

\section{Biomass (kg ha' $\left.{ }^{-1}\right)$}

Biomass was observed significantly different among various varieties of barley (Table 2). The variety Rakhshan-10 produced the highest (4885 $\mathrm{kg} \mathrm{ha}^{-1}$ ) biomass which was followed by cv. Sorab-96 with $3878 \mathrm{~kg} \mathrm{ha}^{-1}$. The biomass decreased to 3829, 3581 and $3164 \mathrm{~kg} \mathrm{ha}^{-1}$ in varieties Awaran-2002, Local Dasht and Sanober-96, respectively. Nevertheless, variety Local Turbat resulted in lowest $\left(2857 \mathrm{~kg} \mathrm{ha}^{-1}\right)$ biomass than all other varieties. The possible reason for difference in biomass may be the differential genetic potential of the varieties tested. Furthermore, [4] reported that cultivars responded differently under diverse agroclimatic condition for various phenological occurrences and ultimately yield components. The results are also in concurrence with [11] who conveyed variance of growth and yield among various cultivars of barley cultivars. 


\section{Conclusions}

The results of present study concluded that growth and yield of barley was significantly affected by genotypic variation. The variety Rakhshan-10 was found to be most appropriate under agro-climatic conditions of Turbat, Balochistan by producing highest grain yield as compared to rest of the tested varieties of barley.

\section{Authors' contributions}

Conceived and designed the experiment: S Din \& N Ahmed, Performed the experiment: S Din \& M Umer, Analyzed the data: M Yaqoob, Contributed reagents/materials/ analysis tools: AA Lashari \& S Ahmed, Wrote the paper: S Din $\&$ MN Kandhro.

\section{References}

1. Thalooth TA, Bahr A \& Tawfik MM (2012). Productivity of some barley cultivars as affected by inoculation under water stress conditions. Elixir Appl Bot 51: 10743-10749.

2. Kamali N, Pour MRK \& Soleymani A (2014). Studying growth indices and grain yield of barley cultivars at planting dates in Isfahan region. Int $J$ Farm Alli Sci 3(1): 35-44.

3. Anjum SA, Xie X, Wang L, Saleem MF, Man C \& Lei W (2011). Morphological, physiological and biochemical responses of plants to drought stress. African $J$ Agric Res 6: 2026-2032.

4. Soleymani A \& Shahrajabian $\mathrm{MH}$ (2013). Survey of the growth length, seed yield and yield components of barley genotypes on the basis of combined analysis under deficit irrigation. Tech J Engg Appl Sci 3(15): 1676-1679.
5. Soudabeh A, Hassanpanah D, Mohebalipour N \& Ghasemi M (2013). Evaluation of genetic diversity genotypes of barley using agronomic and morphological traits. Int J Agron Plant Prod 4(2): 350-354.

6. Shao HB, Chu LY, Jaleel CA, Manivannan P, Panneerselvam R \& Shao MA (2009). Understanding water deficit stress-induced changes in the basic metabolism of higher plantsbiotechnologically and sustainably improving agriculture and the ecoenvironment in arid regions of the globe. Crit Rev Biotechno 29: 131-151.

7. Jairus OJS, Auma PEO, \& Ngode DL (2015). Evaluation of promising malting barley varieties using agronomic and quality traits in Kenya. J Agri Life Sci 2(1): 104-110.

8. Amanullah, Khan A, Khan AA, Fayaz M, Shah P \& Zada K (2008). Evaluation of barley genotypes under water stress condition planted at different seeding rates. Crop Res 36: 37-41.

9. Amanullah, Khan A. Hussain Z, \&Jan D (2010). Performance of wheat cultivars sown at different seeding rates under moisture stress conditions. Archives Agron Soil Sci 56: 99-105.

10. Katerji N, Mastrorilli M, Hoorn JWV, Lahmer FZ, Hamdy A \& Oweis T (2009). Durum wheat and barley productivity in saline-drought environments. European J Agron 31(1): 1-9.

11. Alazmani A (2015). Evaluation of yield and yield components of barley varieties to nitrogen. Int J Agri Crop Sci 8(1):5254. 